jącej wśród społeczeństwa. Wyniki badań własnych na temat sponsoringu - powiązań między zjawiskiem sponsorowania a związkiem - przedstawiła mgr Małgorzata Kozioł, reprezentantka Uniwersytetu Marii Skłodowskiej-Curie w Lublinie. Wystąpieniem zamykającym konferencję była prezentacja mgra Jana Bajora, który skupił się na społeczności fandomów, w których fani mają możliwość ujawnienia swoich (niejednokrotnie) mniejszościowych, a często nieakceptowanych społecznie preferencji seksualnych.

Zainteresowanie problematyką podejmowaną w ramach konferencji, które zostało odnotowane już na etapie zgłoszeń tematów i abstraktów, pokazuje, że tematyka seksu, seksualności i innych aspektów, które się z nimi łączą, przestaje być sferą tabu. Zagadnienia te poruszane są w coraz nowszych kontekstach, za pomocą różnorodnych kanałów komunikacji. Zaprezentowane wystąpienia, odpowiednio przedstawione oraz zrecenzowane, stworzą tematyczny numer „Forum Socjologicznego”.

Paulina Niedopytalska

\title{
„Miasto i Kultura/City and Culture”. Konferencja międzynarodowa, Wrocław, 20-22 września 2017 roku
}

DOI: 10.19195/2083-7763.7.20

Międzynarodowa konferencja „Miasto i Kultura/City and Culture” rozpoczęła się w środę 20 września i trwała do piątku 22 września 2017 roku. Było to trzydniowe spotkanie praktyków i teoretyków kultury, którego głównymi tematami pozostawały prawie dwuletni proces ewaluacji Europejskiej Stolicy Kultury Wrocław 2016 oraz związki miasta i kultury. Organizatorami wydarzenia były: Instytut Socjologii Uniwersytetu Wrocławskiego, Biuro Festiwalowe IMPART 2016, Urząd Miejski Wrocławia we współpracy z Sekcją Socjologii Miasta oraz wrocławskim oddziałem Polskiego Towarzystwa Socjologicznego. Koncepcja konferencji zakładała kilka odmiennych sposobów mierzenia się z jej koronnymi zagadnieniami. W blokach akademickim oraz praktycznym, stanowiących dwa obiegi konferencji, można było wysłuchać referatów (w części naukowej wydarzenia) oraz wziąć udział w debatach, spotkaniach, warsztatach i działaniach artystycznych w podwórku przy ul. Ruskiej 46. Wstęp na większość wydarzeń był bezpłatny.

Dla obrad akademickich były zarezerwowane godziny przedpołudniowe i wczesnopopołudniowe każdego dnia konferencji. Toczyły się one w sali „Kultura” w infopunkcie „Barbara” - nowym miejscu, dedykowanym kulturze w mieście oraz powstałym na okoliczność obchodów Europejskiej Stolicy Kultury we Wrocławiu. Wystąpienia przygotowali referenci z uniwersytetów i ośrodków badawczych w Europie (m.in. z Francji, Niemczech, Wielkiej Brytanii, Węgier, Ukrainy) i w Polsce (reprezentowane były takie instytucje, jak Uniwersytet Wrocławski, Akademia Górniczo-Hutnicza, Politechnika Wrocławska, Teatr Muzyczny w Poznaniu, Uniwersytet Gdański, SGGW, Uniwersytet Warszawski, Szczeciński, Opolski, Śląski i Jagielloński czy Fundacja „Skwer Sportów Miejskich”). Codziennie odbywały się trzy sesje z kilkoma wystąpieniami. Jednego dnia można było zatem wysłuchać około dziesięciu referatów. W sumie czterdziestu jeden badaczy kultury miejskiej 
zaprezentowało dwadzieścia dziewięć wystąpień w dwóch językach: polskim i angielskim (wszystkie wypowiedzi były tłumaczone symultanicznie). W ramach programu skierowanego do pracowników naukowych zostały przedstawione tematy związane m.in. z mikroobiegami kultury (np. „Wrocław - wejście od podwórza”, „mikroGRANTY ESK 2016” oraz „Program Rezydencji Artystycznych A-i-R Wro”), studia przypadków dotyczące rozwoju i redefiniowania kultury na przykładzie Gdańska, Lublina czy francuskiego Arles, zarządzania kulturą w procesach budowania sieci społecznych, rewitalizacji, metropolizacji i partycypacji, a także „efekt ESK”, czyli analiza zmian w polskich miastach, które starały się o otrzymanie tytułu Europejskiej Stolicy Kultury. W części akademickiej uczestniczyli pracownicy naukowi oraz menedżerowie kultury na zasadach konferencyjnych. Całość obrad była dostępna online jako streaming. Ilość i bogactwo udostępnionych w tej części analiz uniemożliwiają szczegółowe ich zreferowanie w tak krótkim komunikacie, dlatego też zainteresowani mogą odwiedzić stronę internetową http://www.wroclaw2016. $\mathrm{pl} /$ miastoikultura, na której możliwe jest zapoznanie się z programem konferencji, oraz pozostałe witryny, na których zamieszczono streaming najważniejszych wystąpień konferencyjnych i debat ${ }^{1}$.

Popołudniowe godziny dni konferencyjnych wypełniały m.in. debaty o kulturze miejskiej z udziałem znamienitych gości, kluczowych twórców i badaczy kultury, a także prezydenta miasta Wrocławia, Rafała Dutkiewicza, oraz dyrektora Departamentu Spraw Społecznych UM Wrocławia, Jacka Sutryka. Punktem wyjścia do refleksji był cykl raportów podsumowujących proces ewaluacji ESK Wrocław 2016, które zostały przygotowane przez zespół z Instytutu Socjologii Uniwersytetu Wrocławskiego. Przedmiotem rozmowy były kondycja sektora kultury, specyfika, dynamiki i przyszłość kultury miejskiej, kulturotwórcza rola miasta oraz miastotwórcza rola kultury, zagadnienia dotyczące uczestnictwa, aktywizacji i relacji miasto-twórca. Pierwsza z trzech debat nosiła tytuł „Kultura miejska”, a udział w niej wzięli Barbara Frydrych (dyrektorka Biura Prezydenta ds. Kultury w Gdańsku), Bogna Świątkowska (Fundacja Bęc Zmiana), Kamila Kamińska (Instytut Pedagogiki Uniwersytetu Wrocławskiego), Edwin Bendyk (tygodnik „Polityka”), Mateusz Błaszczyk (Instytut Socjologii Uniwersytetu Wrocławskiego). Poprowadził ją Max Cegielski (dziennikarz, pisarz). Druga - „Kultura a polityki i strategie rozwoju miejskiego” - była moderowana przez Artura Celińskiego (zastępcę redaktora naczelnego „Magazynu Miasta”, szefa programu „DNA Miasta”) i gościła Bożenę Gierat-Bieroń (Instytut Europeistyki Uniwersytetu Jagiellońskiego), Jacka Plutę (Instytut Socjologii Uniwersytetu Wrocławskiego), Łukasza Medekszę (sekretarz Strategii Wrocławia 2030), Zinę Jarmoszuk (Polski Instytut Sztuki Filmowej) oraz Jacka Sutryka (dyrektora Departamentu Spaw Społecznych, UM Wrocławia). Podczas ostatniego, piątkowego spotkania — „Efekt ESK oraz metodologia badań kultury" - nad nie mniej żywą jak w poprzednich dniach dyskusją gości i publiczności panowała Agata Etmanowicz (Fundacja IMPACT), a głos zabrali: Ra-

1 Pierwsza część akademicka: https://www.youtube.com/watch?v=5sQs4DgWCOk, https:// www.youtube.com/watch?v=HEL0mdtAVTs, https://www.youtube.com/watch?v=hP2zxy W8wHo (dostęp:2.01.2018); druga część akademicka: https://www.youtube.com/watch?v=6Lm8o_ PF0_I (dostęp: 2.01.2018); trzecia część akademicka: https://www.youtube.com/watch?v=XHy9ju Hw4qo, https://www.youtube.com/watch?v=wB5ccEu-PNY (dostęp: 2.01.2018); debata 22/9/17: https://www.youtube.com/watch?v=K1urdEhjK7E (dostęp:2.01.2018); debata 21/9/17: https://www. youtube.com/watch?v=FLaf5VdP51A (dostęp: 2.01.2018). 
fał Dutkiewicz (prezydent Wrocławia), Krzysztof Maj (dyrektor generalny Biura Wrocław 2016), Katarzyna Kajdanek (Instytut Socjologii Uniwersytetu Wrocławskiego), Nemanja Milenković (dyrektorka Fundacji Novi Sad 2021). Debaty były adresowane do przedstawicieli wszystkich inicjatyw związanych z tworzeniem oferty kulturalnej dla mieszkańców, zarazem wstęp na nie był wolny. Rzeczywiście cieszyły się one dużym zainteresowaniem. Wszystkie zgromadziły dużą publiczność, która tłumnie wypełniła salę w „Barbarze” i aktywnie dzieliła się z panelistami refleksją na podejmowane tematy. Rozmowy nie cichły wraz z zakończeniem dwugodzinnych spotkań, lecz przenosiły się w inne miejsca i w mniejsze grona dyskutantów.

W trakcie konferencyjnych dni można było także wziąć udział w bezpłatnych warsztatach, skierowanych przede wszystkim do przedstawicieli środowisk związanych z kulturą, sztuką i edukacją, tworzeniem oferty kulturalnej dla mieszkańców. W programie warsztatów dla praktyków i teoretyków kultury znalazły się m.in. zajęcia Hanny Kostrzewskiej „Jak dane mówią i jak mówić danymi”, Krzysztofa Zientara i Izy Rutkowskiej „Jak sprawić, aby partycypacja nie była koszmarem?”, Szylvii Nagy „LOCOP — Pogłębić partycypację: w kierunku trwałości kulturowej w skali lokalnej” oraz Marty Trakul-Masłowskiej i Magdy Kubeckiej „Jak działa miasto. Tworzenie dobrych miejsc - teoria i praktyka "placemakingu «". W ciągu trzech dni odbyło się ponadto siedem warsztatów pod wspólnym hasłem „Miejski narzędziownik: od teorii do praktyki”, których celem było przygotowanie kreatorów kultury do reagowania na potrzeby odbiorców, współtworzenia miejsc dedykowanych kulturze, realizowania działań opartych na partycypacji, tworzenia sieci współpracy między operatorami kultury oraz przeciwdziałania instrumentalizacji inicjatyw oddolnych.

Jeżeli nie warsztat, to może spacer po mieście lub wizyta studyjna? Taką możliwość stworzyli organizatorzy wszystkim zainteresowanym konferencją, miastem i kulturą. W środę podczas spaceru z Piotrem Jakubem Fereńskim i Joanną Panciuchin można było poszukać odpowiedzi na pytanie „Kto widział modernizm?” lub przyjąć zaproszenie Mai Zabokrzyckiej na wizytę studyjną na Nadodrzu w czwartek oraz Pawła Wojtylaka na Przedmieściu Oławskim w piątek. Osoby odczuwające niedosyt w kwestii mityngów mogły wziąć udział w spotkaniu „Koalicji miast”, a także w „Parallel Structures”. Ponadto na trzy dni podwórko przy ul. Ruskiej 46 stało się przestrzenią realizacji działań artystycznych, wystaw, spotkań, otwartych pracowni i sceną DJ-ską. Można było poznać się i porozmawiać $\mathrm{w}$ mniej formalnych okolicznościach, obejrzeć prace powstałe podczas rezydencji artystycznych i odnoszące się bezpośrednio do miast, w których tworzyły i które badały rezydentki w ramach wystawy „Miasto jako przestrzeń wspólna”.

Konferencja „Miasto i Kultura” to nie tylko badania kultury miejskiej i „efektu ESK”, program warsztatów dla praktyków i teoretyków kultury czy cykl dyskusji wokół miastotwórczej roli kultury i kulturotwórczej roli miasta. To także wspólne działania, zlokalizowane $\mathrm{w}$ jednym $\mathrm{z}$ najważniejszych podwórek Wrocławia. To właśnie tam dni nie tyle miały swój finał, ile przechodziły jeden w drugi przy dźwiękach prezentowanych przez DJ-ów, dla których miejskość jest źródłem inspiracji i którzy tworzą inny element kultury miejskiej - scenę klubową. Podwórko późnym wieczorem zamieniało się w audiosferę, trwającą niemal do godzin porannych. Przez te trzy dni miasto było dostępne poznawczo oraz zmysłowo i można było nie kłaść się spać, tak samo jak ono.

Ewa Banaszak 